\title{
THE SETTLEMENT PATTERNS OF POLISH IMMIGRANTS IN MANCHESTER IN THE CONTEXT OF MOVE FROM MODERN TO POSTMODERN UNDERSTANDING OF PLACE
}

\author{
AGNIESZKA BIELEWSKA \\ Warsaw School of Social Sciences and Humanities, Campus in Wrocław, \\ Ostrowskiego 30, 53-238 Wrocław, Poland \\ E-mail: abielewska@hotmail.com
}

\begin{abstract}
The paper discusses the settlement patterns of Polish immigrants in Manchester as an exemplification of the changes in the understanding of place and spatially rooted identity in the last 50 years, namely its shift from the modern understanding of place as being closed and limited to the postmodern one, which can be understand as being open and consisting of networks. The paper is based on a study carried out in Manchester in the period 2005-2009 on two groups of Polish immigrants: Poles who had settled there after the Second World War and immigrants who arrived there after Poland joined the European Union.
\end{abstract}

Key words: place, national identity, migration, ethnic identity.

\section{INTRODUCTION}

The purpose of this paper is a discussion of the settlement patterns of two groups of Polish immigrants in Manchester as an exemplification of the changes in the understanding of place and spatially rooted identity that has occurred in the last 50 years. The paper discusses how the spatially rooted identity moved from the modern understanding of place as being closed and limited, to the postmodern one which can be understand as being open and consisting of networks.

The paper is based on a study carried out in Manchester in the period 2005-2009 on two groups of Polish immigrants: Poles who settled in the United Kingdom after the Second World War and immigrants who arrived there after Poland joined the Euro- pean Union in May 2004. In both cases their choices of location are explored in the context of their national identity. The dramatic change of the spatial practices between these two groups illustrate the general move from modernity, where stability and clear definitions are valued, to postmodernity, which is a period characterised by flexibility and open choices, and as a result spatially rooted identity moves from being the centre of migrant life to the periphery.

\section{HOW THE IDEA OF THIS RESEARCH CAME INTO BEING}

The research on which this text is based concentrates on the geographies of migrants' national identity. The content of national 
identity is constantly shaped through a dialectical process (Nagel 1994). It is negotiated between the individual, the national group members and outsiders (Song 2003). Membership brings the individual rights, such as participation in the national culture, as well as responsibilities, such as conforming to the group's norms. Belonging demands, to some extent, the sacrifice of individuality. Since national identity refers to the identification that comes from belonging to the nation, and the nation has some territorial features, national identity is rooted spatially.

The presented research is based on the hypothesis that changes in the perception of place, which has resulted from the processes of globalisation, and the development of new communication technologies, have had an impact on national identity, namely its transformation from the collective into the personal, and from the main identity into a more peripheral one.

This paper focuses on the changes in the settlement practices of immigrants as an example of more general processes concerning national identity. The main hypothesis is that post-war Polish migrants, whose identity was shaped as a result of the strong war time nationalism, and post-accession Polish migrants who grew up in a period of globalisation and consumerism, have different spatial behaviour patterns. It was expected that the settlement practices of post-war migrants are strongly related to their national identity, and their Polishness is one of the most important factors when explaining their spatial behaviour, while the post-accession migrants are more individualistic and their spatial choices lack the motivation of national belonging.

The research was conducted at a very particular historical moment. The communist bloc collapsed, and after 15 years of system transformation Poland was finally admitted into the European Union. However, only three countries allowed Polish workers free access into their labour markets, Sweden, Ireland and the United Kingdom. The unemployment rate in Poland was high and thousands of Poles decided to go abroad to look for better opportunities. A common knowledge of English resulted in the UK being the most popular destination. The first choice was London, and then migration spread outside the capital into other cities, towns and villages.

Post-accession migrants discovered in many English towns long-established Polish communities. Those communities consisted of ex-combatants who had remained in the UK after the Second World War, along with their families. The new arrivals and the post-war migrants were Poles, but the Polish identities of both groups significantly differed, and they seemed to understand and perform their Polishness in different ways.

This paper aims to discuss the different settlement practices of two groups of Polish migrants in connection with modern and postmodern conceptions of place and spatially rooted identity. According to the modern understating of place, place is the opposite of space; a dot with clear boundaries (Tuan 1977). The modern national identity of immigrants should reflect such an understanding of space. It should be shaped by a particular vision of a homeland and the destination place. They should see themselves as living in a foreign land, and be clearly separated from their homeland by state borders and distance.

Postmodernism views the place as consisting of networks (Massey 1992). Such a place has no clear boundaries and is connected to other places. Geographical location no longer dictates separation from one place and belonging to another. In the case of migrants, their move does not necessarily exclude them from being part of a place called home. The postmodern national identity should reflect this fluidity.

The presented study shows how the modern and postmodern conception of place can be used to explain the changes in the expression of national identity. The fluidity of new migration is described, for example, by Grabowska-Lusinska and Okolski (2009). There are several other studies that describe the banal forms of national identity, such as food consumption (Rabikowska 2010) or the 
relations between two groups of migrants (Garapich 2008). The importance of the presented research is derived from the fact that it adopts a different theoretical perspective. This research focuses on current mobility and fluidity, while the social sciences are often, using the terminology of Urry (2006), amobile and sedentary.

\section{THE HISTORICAL CONTEXT OF POLISH MIGRATION TO MANCHESTER}

An analysis of the identity reproduction pattern of Polish migrants requires knowledge of the wider historical context of the migration routes of the two groups of Polish migrants in Manchester. Post-war migrants settled in Manchester due to dramatic political circumstances that shaped their identities, and which explains their current attitudes towards post-accession migrants, whose migration is also the result of a dramatic yet very different political and economic situation.

\section{POST-WAR MIGRATION}

The Second World War in Poland began as a result of German and Soviet acts of aggression. Most of the post-war migrants lived in Eastern Poland, and together with 1,600,000 Poles experienced forced deportation to Siberia by the Soviet troops (Zubrzycki 1956). In July 1941 following the Sikorski-Maisky agreement, a Polish Army was created in the USSR, and the USSR granted an amnesty to earlier deported Poles (Gutman 1977). However, in order to leave Soviet territory, they needed to join the Polish Army under General Anders's command. In 1942 the Polish Army and some civilians, in total about 114,000 people, were evacuated to Persia. After the war they were granted the right to stay in the United Kingdom, together with other Polish soldiers who had fought in the British armed forces. ${ }^{1}$

1 Nearly a quarter of million members of the Polish Armed Forces fought under British Command. The Polish Air Force played very distinguished part in the Battle of Britain where Polish contingent was the second largest after the British one (Poland in Exile, n.d.).
The other part of post-war Polish migration in Manchester were the soldiers of the Home Army (Armia Krajowa), a resistance army organised in occupied Poland in 1939 but known under this name from 1942 (Stowarzyszenie Polskich Kombatantów, n.d.). It encompassed the whole country and was active in both the German and Soviet areas of occupation, and its best known operation was the 63-day long Warsaw Rising in the summer of 1944. After the defeat of the Warsaw Rising, soldiers of the Home Army who were taken captive by the Germans and later liberated by the British, together with the soldiers of General Anders Army and Polish soldiers incorporated into the British armed forces comprised the majority of postwar migrants to Manchester. They were all perceived by the communist regime as politically suspect, and their return to Poland may well have resulted in their prosecutions.

Sword et al. (1989) estimate that the maximum number of Poles in Britain at the end of the war was approximately 106,000. By 1 December 1951, according to census statistics, there were 162,339 persons born in Poland who were resident in Great Britain (Burrell, 2006). Over 10 per cent of this Polish community was professional, and around 75 per cent were unskilled. 85 per cent were Roman Catholic (Sword et al. 1989: 449). In subsequent years the number of those born in Poland within this community declined due to the small inflow, the natural aging process and migration (mainly to America or back to Germany) and reached 4,864 persons in Greater Manchester in 2001, and 56,679 in England (Office for National Statistics, 2001).

\section{POST-ACCESSION MIGRANTS}

The change came in 2004 when Poland joined the European Union and the United Kingdom granted Poles the right to work without obtaining a work permit. Mass migration from Poland to the United Kingdom began. The first destination was London but then the migration spread to other towns and cities. Many young Poles arrived in Manchester and the Polish church gained 
hundreds of new attendants. However, the new migrants forged only a few links with the old migrants. There was a two generation gap between the two groups.

The post-accession migrants were born in Poland at the end of the 1970s and in the 1980s, a period in which Poland experienced a demographic boom. When they finished their education they faced the problem of entering the job market. After the transformation of the political system in 1989 , former latent unemployment emerged and grew rapidly as a result of the rationalisation of the economy and a decrease in the demand for Polish products in the former Soviet countries (Towalski 2003). Those most affected by unemployment were young people because of the phenomenon of insider and outsider segmentation of the labour market, whereby 'insiders' do relatively well in growing industries, and 'outsiders' are either employed in declining industries or are unable to enter the labour market because of their inappropriate skills.

Freedom of movement made many of these young Poles consider migration. The exact numbers of migrants are difficult to estimate. To monitor the influx of the migrants from the new member states, the United Kingdom has demanded that the new arrivals register on a programme called the Worker Registration Scheme (WRS). WRS data allows us to estimate the size of the migration; however, as Garapich (2007:4) explains: "this figure does not include the self-employed or people working in the grey economy'. It also does not account for those who left.

According to WRS data presented in Table 1, the number of registered Polish migrảnts grew every year from 2004 up to 2006 , and then decreased. Among the migrants from all the new member states, men made up 56 per cent of the total and migrants in the age range of 18-34 made up 81 per cent of the total number.

The young migrants who came to the United Kingdom did not accord with traditional notions of badly-educated migrants interested in low-paid and low-prestige jobs. Many speak English and 71.6 per cent of them have already finished secondary school or have even obtained a degree (Grabowska-Lusinska and Okolski 2009). This research shows that they intended to broaden their skills and considered a low-paid job to be a temporary necessity.

The remarkable feature of the new migration is its flexibility and temporality. The majority of migrants who have registered on the WRS have declared they are not going to stay in the United Kingdom for more than three months; the second group did not know how long their stay would last (Home Office, 2010). The new migration is a migration that keeps all its options open. Many of these migrants have already overstayed their declared period, but due to their attitude it is hard to call their migration a settlement migration, but should instead be characterised as a fluid migration (Grabowska-Lusinska and Okólski 2009).

\section{RESEARCH}

The research is based mainly on primary qualitative data gathered through semistructured interviews, observation and participant observation. However, secondary data such as church archives, migrants' publications, the press, Home Office data and earrlier reports were also used to build background knowledge.

Table 1: Polish migrants register in WRS according to the year of registration.

\begin{tabular}{lccccccc}
\hline Year & 2004 & 2005 & 2006 & 2007 & 2008 & 2009 & Together \\
\hline $\begin{array}{l}\text { The number } \\
\text { of Polish migrants }\end{array}$ & 61,860 & 114,235 & 151,430 & 149,850 & 100,500 & 62,095 & 639,970 \\
\hline
\end{tabular}

Source: Home Office, 2010 
The interview sample was constructed with the use of the snowball technique (Patton, 1987), with 9 interviews with post-war migrants ( 6 individua1, 2 joint and one group interview) and 22 interviews with post-accession migrants (20 individual, one joint and one group interview). A key objective was to achieve a diversified sample in terms of migrants' job positions, education, gender, relationship status, and migration routes. All interviews were conducted in Polish and translated into English following content analysis.

The biggest methodological problem emerged through the differences between the two groups of Polish migrants. Semistructured interviews were an exhaustive source of information for post-war migrants, who possess a strong and coherent narrative of identity, whereas the post-accession migrants have not formed a narrative of their national identity. In order to avoid the creation of artefacts, participant observation was adopted as an additional method, conducted in a Manchester call centre in which the researcher was employed as a member of the Polish team from December 2006 to December 2007. The number of Poles in the team fluctuated from 6 to 32 .

The researcher also participated in the life of the Polish community in Manchester, which was formed by post-war migrants. Observation allowed, in this case, for analyses of both 'traditional' cultural practices - such as visiting Polish clubs and churches, celebrating religious and national holidays, and sending children to Polish Saturday school - and mundane activities in everyday life which were a great source of knowledge about national identity (Billig 1995; Edensor 2002).

\section{A COMPARISON OF THE TWO GROUPS' SETTLEMENT PATTERNS}

The next part of this paper discusses the different settlement patterns of two groups of Polish migrants in relation to their national identity. It discusses the similarities and differences that have been identified in an at- tempt to illustrate the changes that national identity has undergone over the last 50 years. I start with a section that contrasts the settlement practices of the two groups of Polish immigrants and this is followed by further explanations about the differences between the two groups' identities.

The choice of location is important for geographies of identity, as it is an indicator of social segregation. It may lead to the formation of migrants' enclaves or it may result in the practical invisibility of immigrants.

\section{POST-WAR MIGRANTS SETTLEMENT PATTERNS}

The first group of post-war migrants in Manchester were Polish soldiers who were based at several training centres in the North-West during the Second World War, such as Ringway Airfield, Blackpool, and Wilmslow, including those who were brought for treatment to Davyhulme Hospital. After the war, many of them decided to settle in Manchester (Scragg, 1986). Later they were joined by civilians, and together they formed the Polish community.

Manchester was an attractive location for them due to the existence of its pre-war Polish community ${ }^{2}$ and the cotton industry which offered them employment. The prewar Polish community in Manchester was concentrated around Cheetham Hill and socialised in the Cheetham Hill Road 'Polskie Kolo' (Polish Circle) club. When postwar migrants arrived in Manchester, some of them settled in close proximity to the existing Polish community in Cheetham Hill, while others bought houses in Moss Side, which was at the time the cheapest location in Manchester.

These choices are still visible today. As Table 2 illustrates, the parishioners of the Polish Parish of Divine Mercy are concentrated in two areas of Manchester: Cheetham Hill (M8) in the North and

2 There was a Polish consular office as well as a Polish association Kolo Polski (Polish Circle) in Cheetham Hill Road, which exists to this day, the Kosciuszko Club (1910-1919) and the Polish church (1904-1930) (Scragg, 1986). 
Whalley Range (M16) in the South. The parish is the heart of the post-war community, as this group considers being Polish and being Catholic to be inseparable. In May 2006 the Polish parish had 1456 families consisting of 2349 individuals.

Table 2: Parishioners of Polish Parish of Divine Mercy aggregated according to the postcode where they live.

\begin{tabular}{llll}
\hline Postcode & $\begin{array}{l}\text { Number } \\
\text { of parishioners }\end{array}$ & Postcode & $\begin{array}{l}\text { Number } \\
\text { of parishioners }\end{array}$ \\
\hline M16 & 236 & M7 & 45 \\
M8 & 73 & M32 & 42 \\
M21 & 69 & M19 & 35 \\
M14 & 60 & M20 & 28 \\
M33 & 56 & M22 & 28 \\
M18 & 49 & SK & 142 \\
\hline
\end{tabular}

Source: Polish Parish of Divine Mercy archive in May 2006.

Cheetham Hill is the area with the longest history of Polish settlement (Scragg 1986). Whalley Range is a neighbourhood of Moss Side (M14) where the majority of post-war Polish migrants bought their first houses. Later, many moved out to Whalley Range where the standard of housing was higher than in Moss Side, but was still close to the Polish parish.

The spatial choices of the post-war Polish migrants require analysis. Spatial segregation is a complex phenomenon which can be the result of market forces (e.g. house prices) as well as the rejection of migrants by the host society, or migrants' dependence on solidarity networks composed of similar people to themselves (Bolt at al. 1998). The host society may prefer homogeneity and seek to keep ethnic differentiation to a minimum. Migrants may prefer socio-spatial proximity to their own social group and membership of a community with local services in their home language. The choice of place is influenced by the migrants' strategic choices as well as their social and economic capital, and it can evolve during their lifetimes.
When the migrants first arrived, the places of residence that they chose were influenced heavily by existing social networks. Poles were renting rooms in the houses of other Poles, or they took advantage of their hospitality. They were able to build friendships on the basis of the Polish language and common experience. They had colleagues from the army and from the Polish Resettlement Camps where they were kept after the war.

Joanna $^{3}$, who came to visit the UK and got married within 3 months, explains:

Joanna: And my husband also didn't have anything - any house, he lived as a lodger in some house that belonged to Poles. And later my husband worked and we started saving and, by and by, we bought a house, such a cheap one. So we lived there for 5 years. After 5 years we saved some money and sold this house and bought a better one.

(interview with Joanna, age 76)

Networks of Poles were the only capital these immigrants could use when beginning their new lives. Knowledge of English was quite limited among the immigrants, and was mainly a feature of those with a better education who came from wealthier pre-war families. Migrants also tended not to have any money. Over time they developed some economic and cultural capital by getting jobs, saving and learning the ways of their new society. However, as is showed below, it was not enough to separate them from the Polish community.

Bolek, who came to the UK with the scout section of Anders Army, remembers:

Bolek: First, after arriving, all people were grouped around the church. Later everyone who became better off moved farther and farther [away].

(group interview)

${ }^{3}$ All the respondents' names were changed to protect their identity. The interviews quoted in this text were conducted in 2006. 
Changes in location reflect changes in the migrants' accumulated capital. As they became more resourceful, they moved further away from the church, which was the centre of their community. However, they moved as a group and they chose as their new location the same part of Manchester.

The importance of membership of the Polish community for immigrants is reflected in the fact that that they did not disperse around Manchester, but bought houses close to each other and remained not far from the Polish facilities, such as the church, Polish club and delicatessen. One of the respondents, Karol, explained that when he and his wife bought his current house in Whalley Range there were nine other Polish families living in the same street, and the house opposite belonged to his cousin. He admits that the Polish neighbours were the reason why he decided to buy his current house.

There are also some migrants who decided to move outside of the Polish neighbourhood. One of these couples is Tolek and Weronika. Their decision was connected with the fact that Tolek graduated from an English university and before coming to Manchester he worked for some time for an English company as an architect. This job and his knowledge of English made him more independent. He and his wife did not need to rely on their co-ethnics for help with daily tasks. As the interview data demonstrate, very few migrants from the Polish community had such cultural capital. It made them aspire to a higher social status than the rest of the Polish community and this was expressed through their choice of location.

Weronika: We had wonderful neighbours.

Tolek: They had a small factory. The journalist of the Evening News lived here too, and the owner of a bakery - wealthier people. (...) When we bought this house the good English middle class lived here.

Weronika: When we moved in the professionals lived here - doctors, dentists, bank managers.

(interview with Tolek, age 88 and

Weronika, 80)
Tolek and Weronika aspired to more middle class location. However, they both stayed active within the Polish community where they have important official functions.

In summary, the post-war migrants' choices of places to live conform to a pattern that is well-known in the migration literature (Culter 2005; Massey et al. 1994; Lieberson 1961).

Their choices were motivated by economic and social factors, which lead to a degree of spatial segregation. Their limited economic capital forced them to settle in cheap areas that were occupied firstly by the poor English working class, and later by immigrants. Social factors drove them to settle close to other Poles. With time, their economic situation improved and they moved to better neighbourhoods; however, they did this as a community. Their choice of location within the Polish neighbourhood is significant and is linked to the construction of Polish identity.

The national identity of post-war migrants was shaped firstly in their childhood by the strong patriotism of the nascent Polish state, and in their youth by the Second World War, during which many of them fought as soldiers. Then the power of the myth of the homeland was strengthened by the fact of forced separation. For many years these migrants could not visit their homeland, and the only Poland they had was the one reproduced in Manchester.

The strong need for Polishness is expressed in the creation of two Polish enclaves in the Manchester urban space: first around the pre-war Polish community in Cheetham Hill, where the Polish club Polskie Kolo is located, and the second, bigger one around Mosss Side, where the Polish church, Polish Saturday School and Polish care homes are located. These places are for the post-war migrants an extension of their transnational home, where 'home' is defined as the place where 'difference can be displayed and acted out by speaking a language other than English, and by fostering cultural identities through domestic interiors and material cultures' (Blunt and Dowling 2006: 214). They 
spent a lot of their free time in these places and when they retired, parish meetings became the only form of social life that most of them had. They also mark urban space beyond these Polish sites, mainly through the establishment of monuments and commemorative plates, such as the Katyn Monument in the Southern Cemetery, Chorlton.

\section{POST-ACCESSION MIGRANTS}

This section analyses the ways in which the post-accession migrants choose a place to stay. It presents the routes of three individuals which illustrate three typical ways that post-accession migrants arrived in Manchester. The first one is the au pair route. Before the accession, the au pair programme was one of very few ways to enter legally the United Kingdom for a long-term visit. The second way was to obtain a job offer in England while they were still in Poland, and the third way was to use the migrant network. The analysis focuses on what these three different types of routes say about the character of the current migration in the context of migrant national identity. It also discards some migrant stereotypes regarding this group, such as migrants' vulnerability or the formation of immigrants' enclaves.

\section{The au pair route}

Jadwiga-like many Polish girls who after secondary school did not know what to do with their lives-decided to come to Manchester as an au pair. Being an au pair is a low-risk way of getting to know a foreign country. An au pair agency in Poland sent her to a Zimbabwean family that lived in Woodhouse to take care of their children. In return, she was supposed to learn English and receive some pocket money. She did not know any Polish people at the time, and her daily routine reduced the chances of making new friends. As she says:

Jadwiga: When I came here (...) I didn't know anyone. It was my first time abroad, and I was stressed. I was scared to take the bus on my first day - where would it go? - here everything looks the same, all the buildings are the same. From 8am, in fact from 7.30am when I woke up the boy to go to school, till 9 or 10pm I was with the children. Even when the parents came home, the children were with me.

(interview with Jadwiga, age 22)

She was very tired with this lifestyle and wanted to earn more money, so she terminated her contract after six months. Her two brothers were coming to England and she planned to rent a flat with them. Her employers tried to help her with looking for a new flat, but Jadwiga thinks they had some hidden agenda:

Jadwiga: When they were helping me to look for a flat they chose such bad areas - Moss Side, Cheetham Hill, Salford. They wanted to show me that if I didn't live with them, I needed to leave this higher standard of living.

(interview with Jadwiga, age 22)

Jadwiga noticed that her host family expected that she would look for a room in a cheap area inhabited mainly by other migrants. The concentration of immigrants in migrants' enclaves is a phenomenon often described in the literature on spatial segregation (Culter 2005; Massey et al. 1994; Lieberson 1961). However, while this concept does apply to the post-war migrant group, it does not explain the post-accession migrants' spatial behavior. Jadwiga, like many other Poles who stayed in Manchester for several months, did not feel any sense of belonging to the poor migrant districts. She wanted to live in a 'good' neighbourhood. She also was not interested in the fact that Cheethám Hill and Mosss Side were the centres of the post-war Polish community in Manchester.

The post-accession migrants in Manchester are generally young and educated. They usually do not have a family to support and they aspire to a middle class lifestyle. They left Poland to improve their standard of life, and they are not ready to compromise on their flat and neighbourhood. Jadwiga 
found her current flat through an advert in the Manchester Evening News. It is a twobedroom furnished flat in Sale, close to the restaurant she works in. It costs 500 pound per month. She lives there with her two brothers.

Jadwiga: We are happy living here. The only problem is that we have elderly neighbours so we need to be quiet after 9 or 10 pm. (...) so there are no parties or anything. It is sad. But it is very beautiful here, I need to say, because where I lived before, it was close to a road so cars were passing all the time. Awful...

(interview with Jadwiga, age 22)

Jadwiga is ready to pay more for her flat to live in a nice area. She appreciates the peaceful and beautiful surroundings. She feels offended by the suggestion of her au pair family that she needs to move into the poorer districts of the city. She does not want to be associated with the British working class and does not care about the presence of other Poles. Her choice is motivated by the quality of life, what she can afford and added value - aspiration to a certain social class - so her choice arises more from 'value for money' considerations than those which are related to any association with national identity.

\section{The work agency route}

Monika and her boyfriend planned their future together and they needed money. They visited a job fair in Łódź, their hometown in Poland, and they both got job offers in Britain in the security sector. However, only Monika's boyfriend started a job and she finished her studies in Poland.

Monika's boyfriend accepted the offer of a Polish man that he met at work and took a room in a house shared by several Polish people. When Monika joined him after six months they shared his room. She learnt that the Polish man who offered them the room rented the house from an agency but sublet the property, and did not pay any bills or Council Tax for this property:
Monika: We knew from the beginning that something was wrong. Me and my boyfriend slept in one room, in one bed and we paid double money. I didn't have my own room. I didn't like it. I told my boyfriend we paid too much but he said the situation did have an advantage for us. He came and he had a place to sleep. So we stayed there at the beginning.

(interview with Monika, age 26)

Monika believes that her boyfriend, as a single person without friends, did not have any option but to accept the room. However, he used the support of other Poles only in the first stage of his migration. He then formed his own social network, which he then used to search for a new place once Monika had arrived. The vulnerability of migrants often described in the literature (i.e. Jazwinska and Okolski 2001) comes from the lack of language skills, knowledge about the new society and illegal status. The new arrivals, in contrast to the earlier migration waves, are well-equipped in social and cultural capital and are rarely forced to depend on their $\mathrm{CO}-$ ethnics.

The case of Monika and her boyfriend is an example of moving out from an immigrants' ethnic enclave into the host society. Immediately after their arrival, they were ready to accept any conditions, even if they knew they were not being treated fairly. The next location is chosen more carefully, using accumulated social and financial capital. Monika's social capital, which she used to get later a cheap flat to rent, was that of her work and university colleagues, and not other Polish immigrants. None of these choices of where to live was determined by the desire to live close to other Poles or Polish places.

\section{Migration network}

Julia offers an example of migrants who use their social network in order to begin their migration. She studied physics at university in Poland for two years. She liked her studies but she did not have enough money to continue, so she decided to go abroad. She chose Manchester because she knew a girl who already lived there and she would be able to 
stay with her. However, she left this flat soon after her arrival because she did not approve of her friend's violent relationship with her boyfriend. She decided to move in with her future husband, a young man from Mauritius. She met him the very first day when she started a job in a Pizza Hut where he was the manager. He lived not far from her first location in Chorlton. They then moved together to Moss Side but they did not like it there:

Julia: There were only blacks. God, they are such thieves. They are gangsters.

(interview with Julia, age 21)

The issue of race, which appears in this interview, is a common theme among the post-accession migrants' interviews and it has an important spatial dimension. As white migrants, they feel closer to the English host society than to immigrants from Asia and Africa, and they accept the myth that violence and crime is associated with certain districts of the city where those immigrant groups live. They develop a nuanced mental map of the city that includes notions of safe places and hostile spaces (cf. Robinson, Reeve, and Casey 2007).

Racial categorization is a new theme in Polish migrant identity. Polish society is relatively homogenous and racial differences do not appear on the Polish mental map. Racial identity becomes more of an issue after meeting racial otherness in England. The self-identification of migrants as 'white' is an important new element in their identity formation. It seems more comfortable than adopting a Polish identity since it allows migrants to connect with the host society against other immigrant groups (i.e. Eade, Drinkwater, Garapich 2006).

At the time of the interview Julia and her husband rented a studio flat in Whalley Range and she liked this location:

Julia: I wouldn't like to move anywhere else. I have opened all my bank accounts there. I know all the shops in Chorlton. I wouldn't like to move again.

(interview with Julia, age 21)
She did not look for a network of Polish friends. She claimed her husband is enough for her to feel at home:

Julia: He is my family. I would feel lonely without him. When I come home and he is not there I think - shit - what am I doing here? But when he is home - never. When I was in Poland [ to visit my mum] I had all my friends, family, mum, sister, my dog, all my animals and I was lonelier... I was in Poland 10 days. After 5 days I regretted I had already bought plane tickets and I couldn't change the date. I thought 'Jesus, 5 more days, I will go crazy'.

(interview with Julia, age 21)

In spite of the common expression of racial prejudice among migrants, Julia first dated and then, after several months of co-habitation, married her Mauritian boyfriend. She does not perceive him in any racial way.

These are examples of the typical routes that lead post-accession migrants to Manchester. In terms of understanding their national identity the migrants' attitude towards other Poles during these migration stages is crucial. They often start their migration using institutionalised mechanisms, such as the au pair programme which secures a job offer within Poland. This leads to independence from their ethnic and national group. If they use co-ethnic networks in the primary stage of migration, it is only a short-term solution. They soon have enough resources in the form of social and cultural capital to step out of ethnic-based networks. They make a conscious effort to move out of migrant enclaves, a point which is also noted about other Polish migrant groups (Robinson, Reeve and Cassey 2007; Brown 2003; Kohn 2007). They want to experience their migration as individuals, and not as Polish migrants. They do not contest being a Pole, but they do not want to be a part of the Polish community in Manchester. Generally, the choice of location depends on class identity (or status aspiration) rather than national identity.

The other important phenomenon is the rapid development of racial and class con- 
sciousness and, for a proportion of the Polish migrants, the issue of racism. Racial identity is mobilised among poor Polish migrants to establish a positive identification with the dominant host group. These migrants experience these social distinctions more strongly in England because the Polish population is ethnically homogenous, and socio-econom ic divisions within the Polish society have become more accentuated only in recent years. However, the migrants quickly learn these ethnic and class distinctions in English society, which they do not know from Poland, and they want to be associated with the white working- or middle class in England. Certain areas of the city are avoided, such as council estates in Salford and those areas which are perceived as 'coloured districts', i.e. Moss Side. By contrast, Jewish neighbourhoods are perceived favourably. As white Europeans, they seek to distinguish themselves from what they perceive as the poor life chances of coloured immigrants and demand the same rights as the English majority. The migrants' attitude toward their life conditions can be summarised in following quotation: 'I think, if I am here, why should I have worse conditions than in Poland?' (interview with Inga, age 26). As a result, Polish post-accession migrants have common demographic characteristics and follow similar migration patterns, but these patterns do not lead to the creation of a geographically located community.

The post-war migrants live within the Polish neighbourhood and their choice of location is linked to the construction of Polish identity. Firstly it was a result of both their economic situation and limited social capital, which consisted mainly of the networks they had established and consolidated with their co-ethnics. Currently, however, it is a decision that is primarily socially motivated; that is, they want to live in proximity to Polish institutions and other Poles.

The post-accession migrants may use their co-ethnics' support at the primary stage of migration. However, they make an effort to separate themselves from such dependencies as soon as possible.
Olek: I will be honest. I keep a distance from Polish people. I don't need... I left Poland in ordernot to hang out with Poles. They annoy me.

(interview with Olek, 2006)

They treat migration as an individual experience. They try more or less successfully to replace the links with their co-ethnics with links to the host society. A step in this direction is living in the neighbourhoods to which they aspire, which are composed of the white English middle or working class. However, to be able to afford accommodation in such neighbourhoods, they are often prepared to compromise their comfort and share a house or apartment with several friends.

The group of post-accession migrants who show behaviour patterns more akin to those of the post-war migrants are those who tend to be poorly educated. They may turn up in Polish places (such as the church, Polish club, shops) in order to look for accommodation because their poor language skills make finding rooms through official channels, such as agencies or answering advertisements, very difficult for them. These migrants were underrepresented in the research sample. If they were better represented, then the research findings might change with regard to the individualisation of the migration experience for the post-accession migrant group.

\section{GEOGRAPHIES OF IDENTITY FORMATION}

The choices of location of the two groups of Polish migrants in Manchester were discussed above. This section presents the wider context of their spatial behaviour.

The perception of the role of place in the formation of identity has changed in the last few years, and so, consequently, has the understanding of place. In traditional human geography, places signify a tight and relatively immobile connection between a group of people and a site; this implies the construction of 'us' (people who belong in a place) and 'them' (people who do not) (Cresswell 
2004). However, in the 1990s, the modern perception of place was replaced by a postmodern one, where place is understood as open and consisting of networks (Massey 1992). In this research, the post-war migrants largely continue to live in a world of closed places whereby their domicile in Manchester means that they are separated from their homeland. In contrast, the postaccession migrants live in open places and their living in Manchester is connected by various links with Poland.

When post-war migrants wanted to experience Polishness they needed to reinvent it in Manchester. They created the ethnic institutions to satisfy that need. When the communist bloc collapsed, they were already at a stage of life in which their identity was fully formed and resistant to change. The advent of free movement and yearly visits to Poland did not re-establish their broken links with the homeland. By contrast, when post-accession migrants want to experience Polishness, they can simply travel to Poland, or visit the Polish spaces via the television or internet, or contact their relatives through other new communication technologies.

Since the post-accession migrants still inhabit their homeland, they do not need to reinvent it abroad. They find the shabby atmosphere of traditional Polish clubs outdated and in bad taste. Their sporadic visits are rather the result of curiosity than of patriotic needs. They do not share the consensus of the 'political migrants' about the natural connection between people of the same ethnic origins and ethnic group solidarity.

They are aware of the existence of the Polish church but few of them attend church regularly. Those that do are mainly families with school children, where the parents feel responsible for bringing them up in the Catholic faith. Around one hundred families send their children to the Polish Saturday School, and only a very specific group of males with a basic education who do not speak English are interested in frequenting the discos in the Polish club, 'Polskie Kolo'.

The Polish institutions in Manchester were created by the Polish community for the Polish ethnic group in Manchester. However, the group whose needs they addressed has declined. The post-accession migrants treat these venues merely as part of that which is on offer in the city, and this often fails to meet their needs. They are not accustomed to the collective form of national identity rooted in early twentieth-century traditions, where a strong sense of patriotism was mixed with a strong collective religiousness (Bielewska 2012).

\section{CONCLUSIONS}

The mass mobility of the last fifty years has resulted in a new mobility paradigm in the social sciences (Sheller and Urry 2006; Sassen 2002; Cressweell 2002; Tsing 2002). The presented research examines the impact of mobility on national identity. It shows how the accessibility of the homeland allows for the treatment of national identity as banal and shifts it from the centre of migrants' lives to its periphery.

The post-war Polish migrants and postaccession Polish migrants in Manchester share their places of origin and destination, but the fact that their migration experience are separated by over half century changes the core issue of this experience, and the form and expression of their national identity.

The post-war migrants live in the modern world of closely and clearly defined places and their migration dramatically separated them from their homeland. They grew up expressing the strong patriotism of the $1930 \mathrm{~s}$ and the primary purpose of their lives abroad was the protection of their national identity. They make a conscious effort to recreate in their new location their homeland. They organised in Manchester a vivid community with such institutions as a Polish school, club and parish. They colonise urban spaces with monuments to commemorate events that are considered to be important for their version of national history. It is pattern well known from the literature on migration and especially on diaspora (Cohen, 1997). 
The post-accession migrants live in a postmodern world of open places and unclear boundaries. They live in a translantional space, which includes both Poland and England. New technologies enable them to pay frequent physical or virtual visits to Poland, so the preservation of Polishness in the foreign land is for them less important. The institutions formed by the postwar immigrants are perceived as inadequate for the new migrants' mentality. They treat their Polish identity as a fact that is irrelevant to their migration experience. They prefer to avoid their co-ethnic group and operate mostly in a global urban space and welcome heterogeneous social relationships.

The change of migrants' spatial practices does not mean that national identity does not exist, but it stops being the most important explanatory factor of the post-accession migrants' settlement practices. Following this track, further studies on current migration should cease using ethnic groups as the units of analysis and move towards a more cosmopolitan perspective, where migrants will be treated just as migrants, and divided into different demographic or lifestyle groups.

\section{REFERENCES}

Bielewska, A. (2012), The geographies of national identity: The modern and postmodern national identities of Poles in Manchester, Ethnicities, 12 (1): 86-105.

Billig, M. (1995), Banal Nationalism, London, Sage.

Bolt, G., Burgers, J. and van Kempen, R. (1998), On the social significance of spatial location; Spatial segregation and social inclusion, Journal of Housing and the Built Environment, 13 (1): 83-95.

Blunt, A. and Dowling, R. (2006), Home, London, Routledge.

Brown, B. (2003), White immigrants. A portrait of the Polish community in London, Working Paper No. 5, London, Institute of Community Studies.

Burrell, K. (2006), Moving lives: Narratives of nation and migration among Europeans in postwar Britain, Aldershot, Asgate.
Cohen, R. (1997), Global diasporas. An introduction, London, UCL Press Limited.

Cresswell, T. (2002), Introduction: Theorizing place, in Cresswell, T. and Verstraet, G. (eds.), Mobilizing place, placing mobility, Amsterdam, Rodopi, pp. 11-32.

Cresswell, T. (2004), Place: a short introduction, Oxford, Blackwell.

Culter, D. M., Glaeser, E. L. and Vigdor, J. L. (2005), Is the melting pot still hot? Explaining the resurgance of immigrants segregation, NBER Working 11 295, National Bureau of Economic Research, Inc.

Eade, J., Drinkwater, S., and Garapich, M. (2006), Class and ethnicity-Polish migrants in London. CRONEM, Univeristy of Surrey, <http://www.surrey.ac.uk/Arts/CRONEM/ polish/POLISH_FINAL_RESEARCH REPORT_WEB.pdf.>.

Edensor, T. (2002), National identity, popular culture and everyday life, Oxford, Berg.

Garapich, M. (2008), Odyssean refugees migrants and power: Construction of the 'other' and civil participation within the Polish community in the United Kingdom, in ReedDanahay, D. and Brettell, C. (eds.), Citizenship, political engagement, and belonging: Immigrants in Europe and the United States, New Jersey: Rutgers University Press, pp. $124-43$.

Grabowska-Lusiñska, I. (2007,) Skill shortages, emigration and unemployment in PolandCauses and implications, <http:/www.migrationonline.cz/e-library $/ ? \mathrm{x}=2004866>$.

Grabowska-Lusińska, L. and Okólski, M. (2009), Emigracja ostatnia? [Last emigration?], Warszawa, Wydawnictwo Naukowe Scholar.

Home Office (2010), Home Office Statistical Bulletin 15/10, London, Home Office.

Jaźwińska, E., and Okólski M. (eds.) (2001), Ludzie na hustawce [People on swing]. Warszawa, Wydawnictwo Naukowe Scholar.

Kohn, M. (2007), A very modern migration, Catalyst, <www.catalystmagazine.org>, MarchApril, 9-11.

Lieberson, S. (1961). The Impact of Residential Segregation on Ethnic Assimilation, Social Forces, 40 (1): 52-57.

Massey, D.(1992), A Place Called Home, New Formations, 17: 3-15. 
Massey, D.S., Gross, A. B., and Shibuya, K. (1994), Migration, Segregation, and the Geographic Concentration of Poverty, American Sociological Review, 59 (3): 425-445.

Nagel, J. (1994), Constructing ethnicity: creating and recreating ethnic identity and cult ure, $S o$ cial problems, 41(1): 152-176.

Office for National Statistics (2001), Neighbourhood Statistic, <http://neighbourhood.statistics.gov.uk/dissemination/LeadTableView. do $2 \mathrm{a}=3 \& \mathrm{~b}=276778 \& \mathrm{c}=$ Manchester $\& \mathrm{~d}=1$ $3 \& \mathrm{e}=16 \& \mathrm{~g}=351271 \& \mathrm{i}=1001 \times 1003 \times 1006 \& \mathrm{k}$ $=$ migration $\& \mathrm{~m}=0 \& \mathrm{r}=1 \& \mathrm{~s}=1311343621435$ \& enc $=1 \&$ dom ain $I d=16 \&$ dsFamily $I d=85>$, last accessed October 2011.

Patton, M. Q. (1987), How to use qualitative methods in evaluation, Sage Publications, London.

Poland in Exile (n.d.), <http://www.polandinexile.com/index.html >, last accessed October 2011.

Rabikowska, M. (2010), The ritualisation of food, home and national identity among Polish migrants in London, Social Identities, 16 (3): $377-398$.

Robinson, D. Reeve and K. Casey, R. (2007), The housing pathways of new immigrants.

Sheffield, Joseph Rowntree Foundation.

Sassen, S. (2002), Introduction: locating cities on global circuits, in Sassen, S. (ed.), Global networks, linked cities, New York, Routledge, pp. $1-38$.

Scragg, T. (1986), The Polish community in Manchester and the North West, Unpublished Master dissertation, Manchester Polytechnic, Manchester.

Sheller, M. and Urry, J. (2006), The new mobilities paradigm, Environment and Planning A 38, 207-26.

Song, M. (2003), Choosing ethnic identity, Cambridge, Polity Press.

Stowarzyszenie Polskich Kombatantów w Wielkiej Brytanii [Polish Combatants" Association in Great Britain] (n.d.), <http://spk-wb. com>, last accessed October 2011.

Sword, K., Davis, N. and Ciechowski, J. (1989), The Formation of the Polish community in Great Britain 1939-1950, London, School of Slavonic And East European Studies, University of London.
Temple, B. (1994), Polish identity and community, Manchester, Manchester University, Sociology Occasional Papers.

Towalski, R. (2003), Unemployment in 2002 examined, The European Foundation for the Improvement of Living and Working Conditions, <http:/www.eurofound.europa.eu/ eiro/2003/07/feature/p10307107f.htm>.

Tsing, A. (2002), The global situation, in Inda, J., Reader, A. and Rosaldo, R. (eds.), The Anthropology of Globalization, Oxford, Blackwell, pp. 453-485.

Tuan, Yi-Fu (1977), Space and place: The perspective of experience, Minneapolis, University of Minnesota Press.

Zubrzycki, J. (1956), Polish immigrants in Britain- $A$ study of adjustment, Martinus Nijhoff, The Hague.

Paper first received: June 2011

In final form: December 2011 